\title{
Response of Maize Crop to Water Deficit and Organic Fertilizers Hussein, A. A. ${ }^{1}$; N. M. El- Bialee ${ }^{1}$ and Ilham I. El- Khatib ${ }^{2}$ \\ ${ }^{1}$ Agric. Eng. Res. Inst. "AEnRI", Agric. Res. Center, Doki - Giza - Egypt. \\ ${ }^{2}$ Soils, Water \& Environ. Res. Inst. Agric. Res, Center, Giza. Egypt.
}

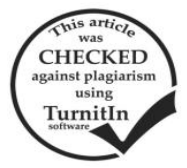

\section{ABSTRACT}

Maximizing irrigation water productivity in irrigated crops, and expansion on organic agriculture are very important to overcome water shortage, and to improve environment preservation. Two field trails (summer seasons 2017 and 2018) were conducted at clay soil to examine the impact of, three amount of irrigation water $(\mathrm{W}) ; 100,85$, and $70 \%$ of $\mathrm{ET}_{\mathrm{C}}$, in conjunction with three fertilizer type; $100 \%$ of NPK $\left(\mathrm{F}_{1}\right), 50 \% \mathrm{NPK}+$ compost tea "CT" $\left(\mathrm{F}_{2}\right)$, and $50 \% \mathrm{NPK}+$ bio-fertilizer "BF" $\left(\mathrm{F}_{3}\right)$, on ear parameters $\left(\right.$ length " $\mathrm{C}_{\mathrm{L}}$ ", No. of row per ear " $\mathrm{C}_{\mathrm{r}}$ ", and grain mass per ear " $\mathrm{C}_{\mathrm{m}}$ "), seed index "SI" (100 grain mass), harvest index "HI", grain yield "G $\mathrm{G}_{\mathrm{y}}$ ", irrigation water productivity "IWP", and NPK uptake at shoots content. A split-plot design was used. Results illustrated that increasing water deficit (WD) percentage, resulted in progressively lower and significantly effect on all traits under study, and WD must not be less than $85 \%$., of $\mathrm{ET}_{\mathrm{C}}$. On the other hand, a combination of organic (CT and/or $\mathrm{BF}$ ) with NPK fertilizer recorded over values at all traits compared of sole NPK. In addition, there were significant effects between $F_{3}$ or $F_{2}$ to $F_{1}$, however, the increase between $F_{3}$ and $F_{2}$, was insignificant.

Keywords: Maize crop, water deficit, organic fertilizer, compost tea, and biofertilizer.

\section{INTRODUCTION}

Water is a vital source for crop production and its resources are limited in Egypt, which consumed about 84\%., of water resources on agricultural sector. Water gap will reach $21.0 \mathrm{Gm}^{3}$., by the 2025 , and the per capita share of fresh water resources is expected to decrease to $350 \mathrm{~m}^{3}$ person $^{-1}$ (El-Beltagy and Abo-Hadeed, 2008). Under serious water shortage and costly supplies, it may occasionally be useful to stress the crop partly. This may decrease crop yield, but it will remain economically feasible, as long as, the marginal benefit from reduced water cost $\geq$ marginal cost of reduced yield. So, foregoing reason leading to improve irrigation water productivity (IWP) in irrigated cropping (produce more yields from less water), which offers one of within solutions to overcome scarcity of water in agriculture sector. This leading to significant water saving, reduced environmental impact of irrigation, reallocate water thus saved to other priority areas and improved sustainability of irrigated agriculture.

Maize (Zea mays L.) is a member of Poaceae family, and called as "King of cereals", as well as, ranked as the third major cereal crop after wheat and rice. Whereat, Egypt cultivated about 2.5 million feddan, to produce about 8.01 teragram., from corn through two periods (summer and nili seasons) (EAS 2017). Meanwhile, irrigation eff. for irrigated maize crop with furrow or check basin, seldom exceeds $50 \%$. Hence, deficit irrigation (or regulated deficit) by reducing water application depth, is one way of maximizing IWP. Where, greater IWP, and max. grain yield were achieved when irrigating to $100 \%$ of $\mathrm{Et}_{\mathrm{c}}$, meanwhile, applying $80 \%$ of $\mathrm{Et}_{\mathrm{c}}$, had insignificant effects on yield reduction compared with the benefits gained through diverting the saved water (El-Khatib et al., 2014).

The huge quantity from chemical fertilizers used in maize production is very expensive, and farmers suffer from scarcity of them during peak season. In addition, chemical fertilizer has negatively effect on human health, and it has an ecological risk, by movement through soil to groundwater or their discharge to surface waters resulting contaminate the soil and underground water. Hence, in organic sustainable agriculture, using renewable resources and inputs, is the main and fundamental goals to maintain soil quality that enhance crop productivity and minimal environmental risk (Meena et al., 2013).
Organic fertilizers includes; farmyard and animal manures, compost, plant residues and bio-fertilizers. Biofertilizer and/or compost application enhance the chemical, physical and biological characteristics of the soil and increase yield and quality characteristics of crops.

Compost tea "CT" is liquid version of the original compost, produce to shift fine particulate of organic matter, microbial biomass, and soluble chemical components of compost into an aqueous phase to applied easily for plant surfaces and soils, for putative fertility and disease control benefits and contribute in reducing chemical-based pesticides and fertilizers in ecosystems (Catello et al., 2014).

It is defined as fermented watery extracts of composted materials and contains soluble nutrients and diversity of bacteria, fungi, protozoa and nematodes. Using CT, in some cases, enhanced the plant yield and quality, by increasing the macronutrient (spastically bioactive $\mathrm{N}$ molecules) in leaf chlorophyll which increases photosynthetic pigment resulting in increasing the yield, and improved the organic matter and microorganisms contents, available soil nutrients, water holding capacity, reduced soil acidity and generally reduced the input costs Reducing diseases of the crops by CT due to resident microbial community (bacteria and fungi) antagonistic actions, and/or improved plant defenses. Compost tea is a liquid extract made by steeping compost in water using two brewing methods: Non-aerated Compost Tea (NCT) or passive brewing, using stable compost without sugar additives, under low oxygen, in an open fermentation vessel through 14 days. Aerated compost tea (ACT) or active brewing, where, mixture was aerated by oxygen till brewing time $(12 \mathrm{~h}$ to 3 days) with adding nutrient and fermentation products rich in microorganisms. Their quality and its effect on plant depend on quality of compost source (raw materials), water quality, bag material, aeration, brewing time, environmental conditions, and water-compost ratio (Pane et al., 2012).

Meanwhile, biofertilizer is a natural input material, contains live formulates of beneficial microorganisms added to a soil, roots or seeds, directly or indirectly, as an alternative, or as a complement of chemical fertilizer in sustainable agriculture, to enhances the availability of different nutrients to the plant, by convert elements from non- usable form to usable form through biological process, as well, inherent metabolic activity. Over conventional chemicals for agricultural purposes to increased yield with 
high quality, bio-fertilizer enhances plant resistance to adverse environmental stresses, e.g., water and nutrient deficiency and heavy metal contamination. Improve soil structure, chemical and biological characteristics, phosphate solutions, as well as, increases, drainage in clayey soil, and reduce erosion potential, safer, nontoxic products and ecofriendly by avoiding any environmental (water or soil) pollution, and offers a cheaper low capital intensive (Beyranv et al., 2013). The biofertilizer therefore may have a potential to decrease the input cost of agricultural production, and be applied to the revegetation of low commercial value sites, such as metal tailings ponds. The efficiency effect of bio-fertilizers due to effect of different strain groups and nutrients mobilizing microorganisms in accelerating the mineralization processes and decomposition of organic wastes and matters and releasing of nutrients resulting in enhancing the utility values of soil organic matter contents that became available for uptake by the plants and cations exchange capacity (Umesha et al., 2014). It includes mainly, nitrogen $\left(\mathrm{N}_{2}\right)$ fixing from atmospheric nitrogen, phosphate (P) solubilizing bacteria to solubilize insoluble $\mathrm{P}$ from soil and fertilizer, and potassium $(\mathrm{K})$ solubilizing bacteria to release $(\mathrm{K})$ from silicate in soil. In view of above facts, present research was planned to assess the influence of combination of organic (compost tea and /or bio fertilizer) and organic fertilizers, with different levels of water deficit on some traits, i.e., ear parameters, seed index, harvest index, grain yield, irrigation water productivity, and NPK uptake

\section{MATERIALS AND METHODS}

Field study was undertaken during two consecutive summer seasons in 2017 and 2018, at Zarzora experimental agricultural station. Eitay El-Barod, ElBehiara governorate, Egypt, which lies at latitude $30^{\circ} 49^{\prime}$ $\mathrm{N}$, long $30^{\circ} 43^{\prime} \mathrm{E}$. Summer season is extremely hot with no rain, where, average temperature of about $33^{\circ} \mathrm{C}$., and high relative humidity more than $70 \%$, during daytime in these months.

Through these experiments, the effectiveness of water deficit "WD" and organic fertilizers "OF" were evaluated on maize (Zea mayz L.) response under open field conditions. The treatment combinations consisted of irrigation water amount $(\mathrm{W}) ; 100 \% \mathrm{ET}_{\mathrm{C}}\left(\mathrm{W}_{1}\right), 85 \% \mathrm{ET}_{\mathrm{C}}$ $\left(\mathrm{W}_{2}\right)$, and $70 \% \mathrm{ET}_{\mathrm{C}}\left(\mathrm{W}_{3}\right)$, and fertilizer type $(\mathrm{F}) ; 100 \%$ of NPK $\left(\mathrm{F}_{1}\right), 50 \%$ NPK + compost tea "CT" $\left(\mathrm{F}_{2}\right)$, and 50\% $\mathrm{NPK}+$ bio-fertilizer "BF" $\left(\mathrm{F}_{3}\right)$. Where, $100 \%$ "ET $_{\mathrm{C}}$ " for maize crop $\approx 2230 \mathrm{~m}^{3}$., as obtained by Egyptian Central Laboratory for Agricultural Climate (CLAC). Meanwhile, $100 \%$ of NPK were 120,60 , and 48 units $\mathrm{fed}^{-1}$., respectively, as recommended by Ministry of agriculture.

White dent maize grains cv. Triple hybrid Giza 320, supplied from Agriculture Crops Research (ARC), were drilled on the $2^{\text {nd }}$ of May 2017 and 2018, and harvested was done on the 15 of August in the $1^{\text {st }}$ and $2^{\text {nd }}$ growing season. In both seasons exp. area was about onethird feddan $\left(1408 \mathrm{~m}^{2}\right)$ included of 27 experimental units (sub- plot). Area was divided into three equal irrigation levels treatments, which considered as main plot, whereas, three fertilizer treatments were distributed randomly in sub-plots. Sub -plot area was $36 \mathrm{~m}^{2}(6 \times 6 \mathrm{~m})$, include eight ridges with $6 \mathrm{~m}$., length and $0.75 \mathrm{~m}$., apart. One meter was left between sub-plots (Horizontal and vertical), as buffer zone. Grains were planted with rate of $14 \mathrm{~kg} \mathrm{fed}^{-1}$, two seeds per hole were dibbled at $3 \mathrm{~cm}$, depth on furrow top with $25 \mathrm{~cm}$, in row spacing seedlings were thinned to maintain only one healthy seedling hill $^{-1}$, three weeks after emergence. Other agricultural practices such as hoeing, earthing up, weeding and sprays against insects, pests and diseases were followed throughout the growing seasons as recommended for conventional maize planting. The main data of the soil are presented in Table 1, as determined according to Klute 1986, meanwhile, textural class name was ascertained from the textural triangle.

\begin{tabular}{|c|c|c|c|c|c|}
\hline \multicolumn{4}{|c|}{ Particle size distribution, $\%$} & \multirow[b]{2}{*}{ Texture } & \multirow{2}{*}{$\begin{array}{l}\text { Bulk density } \\
\text { " } \rho "\left(\text { kg.m }^{-3}\right)\end{array}$} \\
\hline Clay & Silt & \multicolumn{2}{|c|}{ Sand } & & \\
\hline 61.83 & 17.53 & 4.72 & 15.92 & Clay & 1.2 \\
\hline \multirow{2}{*}{$\begin{array}{l}\text { Organic matter } \\
\text { "OM" (\%) }\end{array}$} & \multirow{2}{*}{$\mathrm{pH}$} & \multirow{2}{*}{\multicolumn{3}{|c|}{$\begin{array}{l}\text { Electric conductivity } \\
\text { "Ec" }\left(\text { ds. } \mathrm{m}^{-1}\right)\end{array}$}} & Cations (ppm) \\
\hline & & & & & K \\
\hline 5.50 & 7.63 & & 1.36 & 24.9 & $18.58 \quad 121.29$ \\
\hline
\end{tabular}

Well-decomposed farmyard manure $\left(20 \mathrm{~m}^{3} \mathrm{fed}^{-1}\right)$ was uniformly spread on the soil surface and incorporated two weeks prior drilling for all treatments. $100 \%$ of NPK $\left(\mathrm{F}_{1}\right)$; single super phosphate $\left(15.5 \% \mathrm{P}_{2} \mathrm{O}_{5}\right)$, and potassium sulfate $\left(48 \% \mathrm{~K}_{2} \mathrm{O}\right)$ with rate of 200 and $50 \mathrm{~kg} \mathrm{fed}^{-1}$, were applied and incorporated into the soil during tillage as a basal dose, meanwhile, urea $(46 \% \mathrm{~N})$ top dressed in three equal portions, at drilling time, after 21days from drilling, and before $2^{\text {nd }}$ irrigation.

Aerated compost tea "CT" was prepared in plastic tanks to avoid any air contamination (insects or dust). It made by steeping $10 \mathrm{~kg}$, of nature compost in $100 \mathrm{l}$, of tap water for 5 days with aeration rate of $4 \mathrm{~h} \mathrm{day}^{-1}$, by pumping air through PVC pipe dipped in the barrel using an air compressor. After the incubation time, the liquid mixture was filtered on a 100 mesh screen, and added to plants at the rate of $50 \mathrm{~L} \mathrm{fed}^{-1}$, in two equal doses, subsequent to planting and after 21days from drilling. Natured compost made from rice straw, farmyard manure, betonite, rock phosphate, field spare, elemental sulphure and urea with action of Trichoderma viride and trichoderma harziamum inoculum, which had been composted in thermophilic and aerobic heap for three months. The main traits (physical, chemical and microbiological characteristics) of compost tea "CT" and compost represented (Tables 2 and 3).

Bio-fertilizer, named (BIOGRAMIVA) were prepared by mixing and added five strains; a nitrogen fixing bacterium (Azospirillum brasilense, Azotobacter chrococcum and Bacillus polymxa), and a phosphate solubilizer (Enterobacter agglomerans, and Pseudomonas putida), with portion of $20 \%$ pero-dextrin at a ratio of $1: 1$ (vol /vol ). Strains were maintained on N-deficient combined carbon sources medium, "CCM". They obtained from, the culture collection of Environmental Studies and Research Unit (ESRU), faculty of agriculture, Cairo univ., Egypt. The pollution density of each bacterial culture us $10^{8} \mathrm{cfu} \mathrm{ml}^{-1}$. The liquid bio - fertilizer rate was $81 \mathrm{fed}^{-1}$. This dose was applied to the plants at sowing and then together with irrigation. 
Table 2. The main chemical and microbiological traits of compost tea "CT"

\begin{tabular}{|c|c|c|c|}
\hline$\overline{\mathrm{pH}}$ & 6.82 & Extractable $-\mathrm{Fe}(\mathrm{ppm})$ & 17.3 \\
\hline E.C $\left(\right.$ ds. $\left.m^{-1}\right)$ & 2.69 & Extractable - Mn (ppm) & 2.9 \\
\hline Organic C-C (\%) & 5.81 & Extractable - Zn (ppm) & 5.4 \\
\hline Total $-\mathrm{N}(\%)$ & 0.030 & Extractable $-\mathrm{Cu}(\mathrm{ppm})$ & 1.7 \\
\hline $\mathrm{NH}_{4}^{+}-\mathrm{N}(\mathrm{ppm})$ & 92.8 & $\mathrm{E}_{4} / \mathrm{E}_{6}$ ratio & 3.57 \\
\hline $\mathrm{NO}_{3}^{-}-\mathrm{N}(\mathrm{ppm})$ & 15.6 & $\begin{array}{l}\text { Total countr of bacteria } \\
\left(\mathrm{cfu} . \mathrm{ml}^{-1}\right)\end{array}$ & $7.2 \times 10^{7}$ \\
\hline $\begin{array}{l}\text { Total soluble }-\mathrm{N} \\
(\mathrm{ppm})\end{array}$ & 108.4 & $\begin{array}{l}\text { Total countr of fungi } \\
\left(\mathrm{cfu} . \mathrm{ml}^{-1}\right)\end{array}$ & $6.2 \times 10^{5}$ \\
\hline Available -P (ppm) & 38.6 & $\begin{array}{c}\text { Total countr of } \\
\text { actinomycates }\left(\mathrm{cfu} . \mathrm{ml}^{-1}\right)\end{array}$ & $1.1 \times 10^{6}$ \\
\hline Available $-\mathrm{K}$ (ppm) & 131.4 & $\begin{array}{l}* * * \text { Germination test of } \\
\text { cress seeds }(\%)\end{array}$ & 88.087 .0 \\
\hline
\end{tabular}

Table 3. Some physical, chemical and microbiological traits of compost

\begin{tabular}{|c|c|c|c|}
\hline Bulk density $\left(\mathrm{kg} \cdot \mathrm{m}^{-3}\right)$ & 534.0 & $\mathrm{C} / \mathrm{N}$ ratio & 16.86 \\
\hline $\begin{array}{l}\text { Water holding } \\
\text { capacity }(\%)\end{array}$ & 208.6 & Total-P (\%) & 1.20 \\
\hline $\mathrm{pH}(1: 10$ extract $)$ & 7.00 & Total-K (\%) & 1.64 \\
\hline E.C $\left(\right.$ ds. $\left.m^{-1}\right)$ & 3.52 & Total soluble $-\mathrm{N}\left(\mathrm{mg}, \mathrm{kg}^{-1}\right)$ & 627.3 \\
\hline Organic carbon $(\%)$ & 25.80 & Available-P $\left(\mathrm{mg}, \mathrm{kg}^{-1}\right)$ & 254.2 \\
\hline Organic matter (\%) & 44.38 & Available $-\mathrm{K}\left(\mathrm{mg}, \mathrm{kg}^{-1}\right)$ & 718.3 \\
\hline Total-N (\%) & 1.53 & & \\
\hline \multicolumn{4}{|c|}{ * DTPA - extractable $\left(\mathrm{mg}, \mathrm{kg}^{-1}\right)$ : } \\
\hline $\mathrm{Fe}$ & 174.2 & Total count of bacteria $\left(\mathrm{cfu} . \mathrm{g}^{-1}\right)$ & $3.2 \times 10^{7}$ \\
\hline $\mathrm{Mn}$ & 38.2 & Total count of fungi (cfu. $\mathrm{g}^{-1}$ ) & $1.4 \times 10^{5}$ \\
\hline $\mathrm{Zn}$ & 49.4 & $\begin{array}{l}\text { Total count of actinomycates } \\
\left.\text { (cfu. } \mathrm{g}^{-1}\right)\end{array}$ & $1.2 \times 10^{6}$ \\
\hline $\mathrm{Cu}$ & 5.8 & $\begin{array}{l}\text { Dehydrogenase activity mg } \\
\left(* * \text { TPE } .100 \mathrm{~g}^{-1}\right)\end{array}$ & 181.2 \\
\hline $\mathrm{E}_{4} / \mathrm{E}_{6}$ ratio & 3.57 & $\begin{array}{c}* * * \text { Germination test of cress } \\
\text { seeds }(\%)\end{array}$ & 87.0 \\
\hline
\end{tabular}

* Di-ethylene tri-amine penta acetic acid.

** Tri-phenyl-formazan.

*** Cress seeds incubated for $48 \mathrm{~h}$

Developing surface irrigation system used through 6 inch., $\varnothing(\approx 152.4 \mathrm{~mm})$ aluminum gated pipes, with length about $64 \mathrm{~m}$, and each pipe had 6 circle holes with 1 inch, $\varnothing$ $(\approx 25.4 \mathrm{~mm})$. All plots were irrigated immediately after drilling for uniform germination. The first two irrigations were applied to bring the root zone to the field capacity and, thereafter, irrigation water was applied in the aforementioned amounts. Amount of water irrigation were controlling by gates area and irrigation time. Further irrigation was given at 13 days interval during crop growth, and it was stopped two week prior to harvest. The source of water supply for farm irrigation system was River Nile.

Ten plants, at the inner three rows from each subplots in all replicates, were used for sampling at harvest time. Samples were cut at the ground level, dried in the field, thereafter, tied in bundles and brought to a laboratory. Cobs were separated from the stalks and allowed to dry in sunshine. The following metric traits, i.e., ear parameters included length " $\mathrm{C}_{\mathrm{L}}$ " $(\mathrm{cm})$, No. of row per ear " $\mathrm{C}_{\mathrm{r}}$ ", and grain mass per ear " $\mathrm{C}_{\mathrm{m}}$ " $(\mathrm{g})$, were assessed, and seed index "SI" (100 grain mass per g) were determined. All grains produced from samples " $\mathrm{G}_{\mathrm{sm}}$ " shelled, cleaned, dried and weighed to calculate mass of grain yield " $\mathrm{G}_{\mathrm{y}}$ " $\left(\mathrm{Mg} \mathrm{fed}^{-1}\right)$ by the following eq.

$$
\mathbf{G}_{\mathbf{y}}=\frac{4200 \times \mathrm{G}_{\mathrm{sm}}}{0.75 \times 0.25 \times 10 \times 1000} \approx \mathbf{2 . 2 4} \times \mathbf{G}_{\mathrm{sm}}
$$

Where, $G_{\mathrm{sm}}$ is all grains produced from samples $(\mathrm{kg}), \mathbf{4 2 0 0}$ is feddan area $\left(\mathrm{m}^{2}\right), 0.75$ is a distance between rows $(\mathrm{m}), 0.25$ in row space $(\mathrm{m}), 10$ is plants number, and 1000 is converted coefficient from $\mathrm{kg}$ to $\mathrm{Mg}$.

Meanwhile, harvest index "HI" (\%), and irrigation water productivity "IWP" ( $\left.\mathrm{kg} \mathrm{m}^{-3}\right)$ were computed with hereinafter eqs.

$$
\begin{aligned}
\mathbf{H I} & =\frac{\text { Grain yield " } \mathrm{G}_{\mathrm{y}} \text { " }\left(\mathrm{kg} \mathrm{fed}^{-1}\right)}{\text { Biomass yield }\left(\mathrm{kg} \mathrm{fed}^{-1}\right)} \times 100 \\
\mathbf{I W P} & =\frac{\text { Grain yield " } \mathrm{G}_{\mathrm{y}} \text { " }\left(\mathrm{kg} \mathrm{fed}^{-1}\right)}{\text { Total applied water "TAW" }\left(\mathrm{m}^{3} \mathrm{fed}^{-1}\right)}
\end{aligned}
$$

NPK uptake at shoot content $\left(\mathrm{mg} \mathrm{g}^{-1}\right)$, were analysis as described by AOAC, 2005. The experimental design is a split-plot design with three replicates and two factors. Main factor: Effects of amount of irrigation water $(\mathrm{W})$, and Second factor: Fertilization type $(\mathrm{F})$, and data generated from the field experiments were subjected separately to the proper statistical analyses of variance according to Gomez and Gomez, 1984. Mean comparison between treatments and their interactions was determined using least significant difference (LSD) test at a 0.05 probability significance level.

\section{RESULTS AND DISCUSSION}

Organic fertilizers and water deficit effects on ear parameters, i.e., ear length " $\mathrm{C}_{\mathrm{L}}$ " $(\mathrm{cm})$, No. of rows/ear " $\mathrm{C}_{\mathrm{r}}$ " and grain mass /ear " $\mathrm{C}_{\mathrm{m}}$ " $(\mathrm{g})$, in two growing seasons, were represented in Table 4 . These results showed that using organic fertilizers lead to increase the means of $C_{L}, C_{r}$, and $\mathrm{C}_{\mathrm{m}}$. Furthermore, increase water deficit "WD" lead to decrease ear parameters. In $1^{\text {st }}$ season, $\mathrm{C}_{\mathrm{L}}$ increased about 2.91 and $5.19 \mathrm{~cm}$., from $\mathrm{F}_{1}(100 \%$ of NPK $)$ to $\mathrm{F}_{2}(50 \%$ $\mathrm{NPK}+$ compost tea "CT"), and $\mathrm{F}_{3}(50 \% \mathrm{NPK}+$ biofertilizer "BF"), at $\mathrm{W}_{1}\left(100 \%\right.$., $\left.\mathrm{ET}_{\mathrm{C}}\right)$, and about 2.93 and $5.74 \mathrm{~cm}$., at $\mathrm{W}_{2}\left(85 \%\right.$., $\left.\mathrm{ET}_{\mathrm{C}}\right)$, as well, about 2.4 and $2.7 \mathrm{~cm}$., at $\mathrm{W}_{3}\left(70 \%\right.$., $\left.\mathrm{ET}_{\mathrm{C}}\right)$. Beside, $\mathrm{C}_{\mathrm{r}}$ was increased from 12.75 , 12.45 , and 10.95 for $F_{1}$ to $13.75,13.62$, and 11.80 for $F_{2}$ and to $14.10,14.05$ and 11.09 , for $F_{3}$, at $W_{1}, W_{2}$, and $W_{3}$ respectively. Moreover, application of organic fertilizers $\left(F_{2}\right.$ and $\left.F_{3}\right)$ resulted in 110.33 and $114.01 \%$., extra $C_{m}$ over control. Meanwhile, ear parameter means were increased from $\mathrm{F}_{1}$ to $\mathrm{F}_{2}$, or $\mathrm{F}_{3}$, about (16.46 and $\left.26.31 \%\right)$, (8.82 and $11.59 \%)$, and $(9.22$ and $13.12 \%)$ for $\mathrm{C}_{\mathrm{L}}, \mathrm{C}_{\mathrm{r}}$, and $\mathrm{C}_{\mathrm{m}}$, respectively, in $2^{\text {ed }}$ season. Further, it is evident from data presented that pronounced decreases in ear parameters were achieved as a result of increase WD. Wherein, $C_{L}, C_{r}$, and $\mathrm{C}_{\mathrm{m}}$ had negative direct proportion with $\mathrm{W}$ at al $\mathrm{F}$. The highest values of them were recorded at $\mathrm{W}_{1}$, meanwhile, the lowest values of them were recorded at $\mathrm{W}_{3}$, for two seasons. With regard to obtained results demonstrated, data indicated clearly that ear parameters $\left(\mathrm{C}_{\mathrm{L}}, \mathrm{C}_{\mathrm{r}}\right.$, and $\left.\mathrm{C}_{\mathrm{m}}\right)$ were affected significantly by using combination of organic fertilizer (compost tea "CT" or bio-fertilizer "BF") with nitrogen mineral fertilizer for two seasons. Also, they were affected significantly by $\mathrm{W}$, except $\mathrm{C}_{\mathrm{r}}$ at both growing seasons. Meanwhile, both $\mathrm{F}$ and $\mathrm{W}$, did not effect on ear parameters significantly from $\mathrm{W}_{1}$ to $\mathrm{W}_{2}$. In $1^{\text {st }}$ and $2^{\text {nd }}$ seasons, significant effect of $\mathrm{W} \times \mathrm{F}$ was found at $\mathrm{C}_{\mathrm{m}}$ only. These results are in agreement with Meena et al., 2013, Umesha et al., 2014, and Farnia and Torkman, 2015. 
Table 4. Ear parameters (ear length " $C_{L}$ ", No. of row per ear " $C_{r}$ ", grain mass per cob " $C_{m}$ ") affected by fertilizer type " $F$ " and amount of irrigation water "W" for two growing seasons

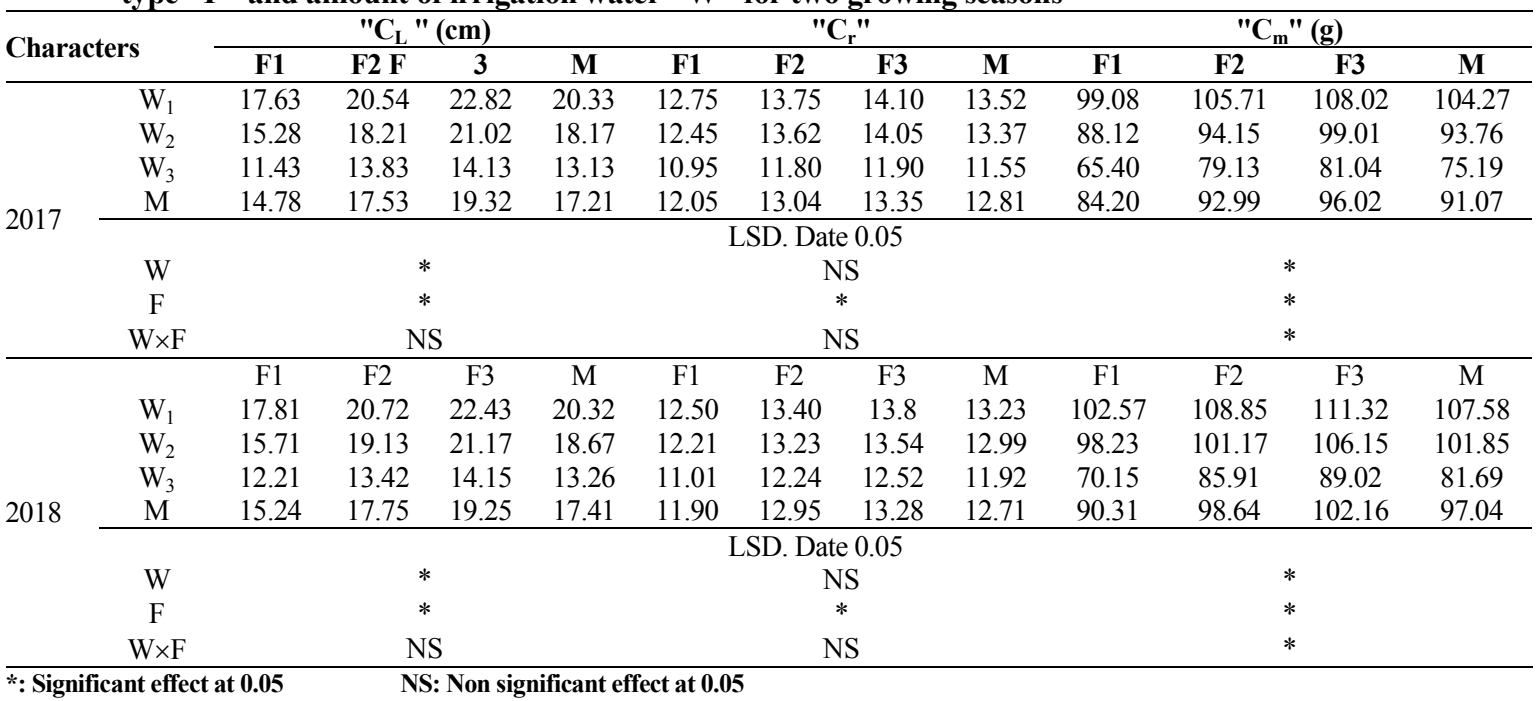

Average seed and harvest indexes "SI and HI", grain yield " $\mathrm{G}_{\mathrm{y}}$ " and irrigation water productivity "IWP" as affected by $\mathrm{F}$ and $\mathrm{W}$ were represent at Table 5.

Combination of organic fertilizer (compost tea "CT" or bio-fertilizer "BF") with nitrogen mineral fertilizer $\left(\mathrm{F}_{2}\right.$ and $\mathrm{F}_{3}$ treatments) led to augment SI (g) under different levels of water as shown in table 6. Results reveled that SI increased about 115.41, 117.55 and $105.06 \%$., from $F_{1}$ to $F_{2}$, and about $130.82,133.28$ and $109.22 \%$ from $F_{1}$ to $F_{3}$ at
$\mathrm{W}_{1}, \mathrm{~W}_{2}$, and $\mathrm{W}_{3}$ respectively in $1^{\text {st }}$. Further, it is evident from data present in table that pronounced decreases in SI were achieved as a result of increased water deficit. Wherein, it had negative direct proportion with $\mathrm{W}$ at al $\mathrm{F}$ treatments. The highest values $(43.32$ and $42.15 \mathrm{~g})$ were recorded at $\mathrm{W}_{1} \mathrm{~F}_{3}$, treatment, meanwhile, the lowest values (28.48 and $28.15 \mathrm{~g}$ ) were obtained at $\mathrm{W}_{3} \mathrm{~F}_{1}$ treatment, for two seasons.

Table 5. Seed index "SI", harvest index "HI", grain yield "Gy" and irrigation water productivity "IWP", affected by fertilizer type " $F$ " and amount of irrigation water "W" for two growing seasons

\begin{tabular}{|c|c|c|c|c|c|c|c|c|c|}
\hline & \multicolumn{4}{|c|}{2017} & \multicolumn{4}{|c|}{2018} \\
\hline & & $\begin{array}{l}\text { "SI" } \\
\text { (g) }\end{array}$ & "HI" & $\begin{array}{c}" \mathrm{G}_{\mathbf{Y}} \\
\left(\mathrm{Mg} \mathrm{fed}^{-3}\right)\end{array}$ & $\begin{array}{l}\text { "IWP" } \\
\left(\mathrm{kg} \mathrm{m}^{-3}\right)\end{array}$ & $\begin{array}{c}\text { "SI" } \\
\text { (g) }\end{array}$ & "HI" & $\begin{array}{c}" \mathrm{G}_{\mathbf{Y}} " \\
\left(\mathrm{Mg} \mathrm{fed}^{-1}\right)\end{array}$ & $\begin{array}{l}\text { "IWP" } \\
\left(\mathrm{kg} \mathrm{m}^{-3}\right)\end{array}$ \\
\hline$\overline{\mathrm{W}_{1}}$ & & 38.22 & 61.97 & 3.69 & 1.65 & 38.69 & 60.28 & 3.57 & 1.59 \\
\hline $\mathrm{W}_{2}$ & & 37.33 & 58.64 & 3.13 & 1.64 & 37.80 & 57.52 & 2.98 & 1.57 \\
\hline $\mathrm{W}_{3}$ & & 30.23 & 47.77 & 1.84 & 1.17 & 29.2 & 49.79 & 1.65 & 1.06 \\
\hline $\mathrm{LSD}_{0.05}$ & & NS & $*$ & $*$ & $*$ & $*$ & $*$ & $*$ & $*$ \\
\hline$\overline{F_{1}}$ & & 31.30 & 50.65 & 2.50 & 1.29 & 31.87 & 50.70 & 2.37 & 1.22 \\
\hline $\mathrm{F}_{2}$ & & 35.36 & 57.37 & 3.02 & 1.54 & 35.66 & 57.57 & 2.82 & 1.45 \\
\hline $\mathrm{F}_{3}$ & & 39.12 & 60.35 & 3.14 & 1.62 & 38.16 & 59.31 & 3.02 & 1.54 \\
\hline $\mathrm{LSD}_{0.05}$ & & $*$ & $*$ & $*$ & $*$ & $*$ & $*$ & $*$ & NS \\
\hline \multirow{3}{*}{$\mathrm{W}_{1}$} & $\mathrm{~F}_{1}$ & 33.12 & 55.07 & 3.15 & 1.41 & 34.13 & 53.11 & 3.05 & 1.36 \\
\hline & $\mathrm{F}_{2}$ & 38.22 & 63.48 & 3.88 & 1.74 & 39.8 & 63.41 & 3.68 & 1.65 \\
\hline & $\mathrm{F}_{3}$ & 43.32 & 67.36 & 4.05 & 1.82 & 42.15 & 65.31 & 3.99 & 1.78 \\
\hline \multirow{3}{*}{$\mathrm{W}_{2}$} & $\mathrm{~F}_{1}$ & 31.94 & 53.85 & 2.67 & 1.40 & 33.34 & 51.99 & 2.52 & 1.32 \\
\hline & $\mathrm{F}_{2}$ & 37.51 & 59.42 & 3.29 & 1.73 & 38.17 & 59.09 & 3.09 & 1.63 \\
\hline & $\mathrm{F}_{3}$ & 31.51 & 51.06 & 1.95 & 1.24 & 30.42 & 51.14 & 1.72 & 1.10 \\
\hline \multirow{3}{*}{$\mathrm{W}_{3}$} & $\mathrm{~F}_{1}$ & 28.84 & 43.05 & 1.69 & 1.08 & 28.15 & 48.01 & 1.54 & 0.99 \\
\hline & $\mathrm{F}_{2}$ & 30.36 & 49.22 & 1.89 & 1.21 & 29.03 & 50.21 & 1.69 & 1.08 \\
\hline & $\mathrm{F}_{3}$ & 42.54 & 62.65 & 3.43 & 1.80 & 41.91 & 61.47 & 3.35 & 1.76 \\
\hline $\mathrm{LSD}_{0.05}$ & & NS & $*$ & NS & $*$ & NS & NS & NS & NS \\
\hline
\end{tabular}

*: Significant effect at $0.05 \quad$ NS: Non significant effect at 0.05

Harvest index "HI" (\%) represent the crop eff. to switch photosynthesized products into economically valuable form. Exposing maize plant to the highest level of $\mathrm{W}_{1}$ caused positive effect on $\mathrm{HI}(61.97$ and $60.28 \%)$ in $1^{\text {st }}$ and $2^{\text {nd }}$ season. In $1^{\text {st }}$ of $\mathrm{HI}$ values ranged from (43.05 to $55.07 \%),(49.22$ to $63.48 \%)$, and $(51.06$ to $67.36 \%)$ at $F_{1}$, $\mathrm{F}_{2}$, and $\mathrm{F}_{3}$ respectively. Max. and min. values of $\mathrm{HI}$ were obtained at $\mathrm{F}_{3} \mathrm{~W}_{1}(67.36 \%)$ and $\mathrm{F}_{1} \mathrm{~W}_{3}(43.05 \%)$ treatments. Meanwhile, in $2^{\text {nd }}$ season "HI" ranged from (53.11 to
$65.31 \%),(51.99$ to $61.47 \%)$, and (48.01 to $51.41 \%)$ for $\mathrm{W}_{1}, \mathrm{~W}_{2}$, and $\mathrm{W}_{3}$, respectively. Where, max., and min. values of $\mathrm{HI}(65.31$ and $48.01 \%)$ were recorded at $\mathrm{F}_{3} \mathrm{~W}_{1}$ and $\mathrm{F}_{1} \mathrm{~W}_{3}$ treatments.

The attained results summarized in Table 5, revealed that maize $G_{y}$ was increased significantly and gradually by increasing water level from $\mathrm{W}_{3}$ to $\mathrm{W}_{2}$ or $\mathrm{W}_{1}$, during two experimental seasons. For example, $\mathrm{G}_{\mathrm{y}}$ was increased by 70.11 and $100.54 \%$., and 80.61 and $116.36 \%$, 
when plants irrigated at the level of $\mathrm{W}_{2}$ and $\mathrm{W}_{1}$, consecutively as compared with those irrigated at the level $\mathrm{W}_{3}$, in $1^{\text {st }}$ and $2^{\text {nd }}$ seasons. Respecting $F$, maize $G_{y}$ grown under $\mathrm{F}_{2}$ and $\mathrm{F}_{3}$ produced the highest yield (3.02 and 3.14 $\left.\mathrm{Mg} \mathrm{fed}^{-1}\right)$ in $1^{\text {st }}$ season, and $\left(2.82\right.$ and $\left.3.02 \mathrm{Mg} \mathrm{fed}^{-1}\right)$ in $2^{\text {nd }}$ season. The interaction between $\mathrm{W} \times \mathrm{F}$ was insignificant in both seasons. That may be due to the independent and inconsistent effects of $\mathrm{W}$ and $\mathrm{F}$ on this character.

Eventually, IWP was significantly decreasing with WD. The reduction of IWP in $1^{\text {st }}$ season reached to 29.09 and $28.65 \%$ from $W_{1}$ or $W_{2}$ to $W_{3}$. As, $G_{y}$ results, IWP did not affect by WD significantly from $\mathrm{W}_{1}$ to $\mathrm{W}_{2}$. IWP of maize plants were improved significantly when used organic fertilizer (CT and/or $\mathrm{BF}+50 \%$ of mineral NPK). The augmentation of IWP reached to 119.38 and $125.58 \%$., at $1^{\mathrm{st}}$ season, and about of 118.85 and $126.23 \%$, at $2^{\text {nd }}$ season for $F_{1}$ to $F_{2}$ and $F_{3}$, respectively. These results are conformity with findings of Mohammed et al., 2018.

The results of macronutrient uptake of shoot content under various treatments for the mean of two growing seasons are illustrated in figure 1. It is obvious from results that combination between organic fertilizer (CT or BF) with $50 \%$, of mineral NPK, had significant constructive effects on NPK uptake of shoot content at 5\% level of significant. In contrast, WD has constrictive and significantly effects at the same significant level. Over and above, the interaction between $\mathrm{F}$ and $\mathrm{W}$ in the two growing seasons was significant. That may due to the independent and inconsistent effect of them on these characters (Data not shown). Regarding to $\mathrm{N}$ uptake, it was influenced by 128.3 and $150 \%$., for $\mathrm{W}_{1}$ and $\mathrm{W}_{2}$ in compared to $\mathrm{W}_{3}$, and 165.88 and $205.88 \%$., for $F_{2}$ and $F_{3}$ in compared to $F_{1}$. Meanwhile, Phosphorus - shoot contents was increase about 117.64 and 158.82 for $F_{2}$ and $F_{3}$ over $F_{1}$, and 122.22 and $138.88 \%$ for $\mathrm{W}_{1}$ and $\mathrm{W}_{2}$ over $\mathrm{W}_{3}$. Above and beyond, $\mathrm{K}$ uptake (shoot contents) was decreasing about 3.50 and $15.38 \%$., for $F_{2}$ and $F_{3}$ to $F_{1}$, meanwhile, increasing WD percentage resulted in progressively lower $\mathrm{K}$ uptake. Where, at $\mathrm{W}_{1}$ treatment, $\mathrm{K}$ - shoot content was $0.60,0.61$ and $0.69 \mathrm{mg} \mathrm{g}^{-1}$., while it reduced to $0.50,0.54$ and 0.60 $\mathrm{mg} \mathrm{g}^{-1}$., as WD percent increased from $\mathrm{W}_{1}$ to $\mathrm{W}_{3}$ for $\mathrm{F}_{1}, \mathrm{~F}_{2}$ and $F_{3}$, respectively. The results corroborated the findings of El-Khatib et al., 2014.

By observing abovementioned results confirmed that, reducing WD with concomitance use of inorganic (chemical) and organic fertilizers "BF" and/or "CT" were effected positively and significantly on aforementioned studied characters. Where, increasing WD percentage resulted in gradually lower all studied parameters, which affected negatively following 100, 85 and $70 \%$., $\left(\mathrm{W}_{1}, \mathrm{~W}_{2}\right.$ and $\mathrm{W}_{3}$ ). Khalill 2013, reported that soil water potential was decreased by drought stress, consequently, plants reduce their osmotic potential for water absorption by congestion of soluble carbohydrates, proline and osmotic regulation (which help to cell development and plant growth, leading to depression in terminal internodes length, which affected plant height and growth and reduction on biological yield (biomass) and HI. On the other hand, decreased in the leaf area owing WD which seemingly, reduced chloroplasts size by modifies their inner structure, causes internal chloroplast membranes degradation. Therefore, reduce total chlorophyll II, about $12 \%$, inhibiting photosynthesis rate and activity about $42 \%$., by harms the photosynthetic apparatus, restrain transfer of stored substance into grains, and consequently accumulation of dry matter, this can be the cause of the decrease of mass and number of grains/cob, similar results was also realized by Alqudah et al., 2011. In addition, WD reduce plant leaves relative water content and modifies some enzymes activity and sugars and proteins accumulation in the plant, then accelerated days of flowering, with disrupted them. It is interesting to mention that, WD during booting or milk -ripe stage at the grain filling period (shorter grain filling duration) reduce assimilate for grain filling and retains location on stored assimilates to the grain which in turn led to reduction in grain size, SI and dramatically reduces $\mathrm{G}_{\mathrm{y}}$. On the other hand, Abd El-Kader et al., 2010 pointed that, amount of irrigation water hade a direct positive proportion with uptake of NPK. Where, most reduction in IWP due to decrease total water applied according to the deficit percent and therefore due to the decreasing in seed yields (Aboamera, 2010).

The availability of nutrients in organic fertilizers does not depend on its total content of the material, but on the dynamics of the process; thus, some elements can become more available because of $\mathrm{pH}$, moisture, and aeration, or in composting for the temperature allowing the development of specialized organisms.

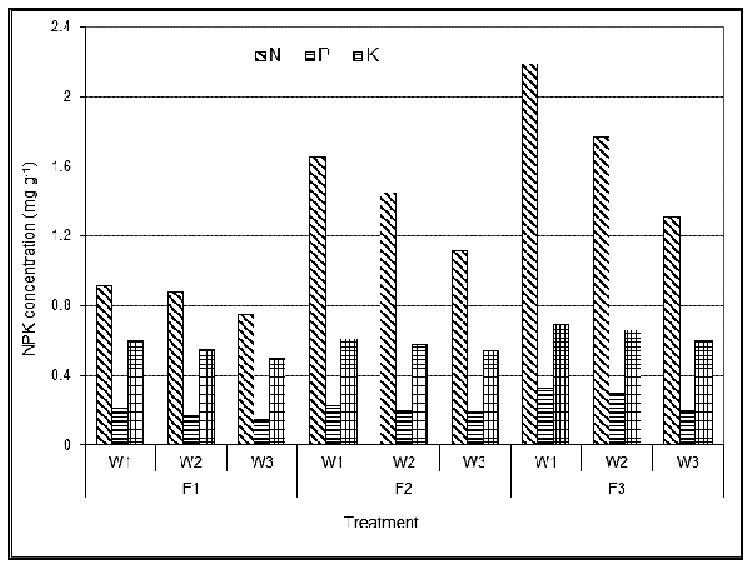

Fig. 1. NPK uptake of shoot contents by Z. mays under different treatments for the mean of two growing seasons.

In contrast, of $\mathrm{WD}$, preceding results give clear idea about stimulated significant effects of conjoint use of inorganic and organic fertilizers on current studied parameters, compared with sole application of chemical fertilizers. Where, combination use of NPK with organic fertilize as CT, plays an important role, because each organic and inorganic fertilizer has its own function to perform. They had a constructive impact on studied traits by enhancing mineralization process of soil organic nitrogen, increased soil acidity and consequently convert insoluble of phosphorus into soluble ones and increase the humus content. The augmentation could be attributed to the stimulation of growth; directly by improving nutrient availability and enhanced nutrient use eff., or indirectly by promoting plants cation exchange capacity (Umesha et al., 2014). Where, CT is considered as a pool of nutrients for 
plants containing significant amount of macro-nutrient, i.e., $\mathrm{N}, \mathrm{P}$ and $\mathrm{K}$, as well, its beneficial effect on soils physical, chemical and biological properties, plant ability to utility fertilizer, and preventing them from becoming permanently unavailable to plants. Data of N, P and K concentrations in maize shoots pronounced increase with combination of CT with inorganic fertilizer (Khaled et al., 2011). Where, the aerated CTs were increase soil microbial biomass and $\mathrm{K}$ content. This effect may be attributed to the role of mineral fertilization in increasing the absorption and accumulation of potassium in the plant organs.

Adding nitrogen and phosphor fertilizer is very important in agriculture to acquire highest grain yield. Hence, promoting effect of BF may resulted from its ability to increase nutrients mineralization bioavailability (nitrogen, phosphorus and other nutrients) in the soil, around the root plants, enhanced nutrient eff. uptake in the rhizospheric soil and help supplying them to the plants. Where, Azotobacter sp. and Bacillus sp. as $\mathrm{N}_{2}$ fixers, and Pseudomonas sp. as $\mathrm{P}$ solubilizer, encourage nitrogen fixation on root zone, and enhanced phosphorus release, leading to promote root system by increases cell division and enlargement, as well, increases dry weight and elongation of shoots at the prestilking stage. Over and above, effecting on metabolic process in plan organs, consequently increased of leaf area per plant, improved plants photosynthetic capacity, and better transfer of photosynthetic substances, this results is in accord with (Rudresh et al., 2004). These arguments are most probable explanation of increasing trait values and NPK uptake as a direct effect of combined use of inorganic fertilizer and biofertilizer. Where, Stimulation of different crops by bio fertilizer on wheat yield increased up to $30 \%$ with Azotobacter inoculation and up to $43 \%$ with Bacillus inoculants and a 10-20\% yield increase, using a combination of B. megaterium and A. chroococcum, meanwhile, strains of Pseudomonas have increased root and shoot elongation in canola, lettuce and tomato.

The former results clarified that, all maize parameters under current studied were affected positively following $\mathrm{W}_{1}, \mathrm{~W}_{2}$ and $\mathrm{W}_{3}$., as well, $\mathrm{F}_{1}, \mathrm{~F}_{2}$ and $\mathrm{F}_{3}$. Statistically results showed that there were significant effects between $\mathrm{W}_{1}$ or $\mathrm{W}_{2}$ to $\mathrm{W}_{3}$. Meanwhile, the difference between $\mathrm{W}_{1}$ and $\mathrm{W}_{2}$ did not reach to a significant level. Despite, all traits were recorded over value with $F_{3}$ compared with $F_{2}$ and $F_{1}$. Moreover statistic results showed that there were significant effects between $F_{3}$ or $F_{2}$ to $F_{1}$. However this increase was insignificant between $F_{3}$ and $F_{2}$. In addition, influence of bio-fertilizers with mineral NPK on maize traits may be attributed to microorganisms not only had positive effect on better root development which resulted in more nutrient uptake by improved mineral nutrition of soil, but also, produce amino acids, vitamins and growth promoting substances like indole acetic acid (IAA), gibberellic acid and bscisic acid, which resulted in enhanced nutrient uptake, translocation and synthesis of photosynthetic assimilates for the betterment of plant growth (Suke et al., 2011). As well as, returns to about $14.38 \%$ of nitrogen on $\mathrm{CT}$ in $\mathrm{NO}_{3}$ form, had negative charge resemble with soil charge which makes it difficult for the soil to retain and quickly inspect leaching through irrigation water or by volatilization.

\section{CONCLUSION}

The foregoing results clarified that, response of studied traits were obviously decreased by withholding water, with insignificant effect between $100 \%$ and $85 \%$., of $\mathrm{ET}_{\mathrm{c}}$, and water deficit must not be over than $15 \%$., $\mathrm{ET}_{\mathrm{c}}$. On the other hand, a combination of organic (CT and/ or BF) with mineral NPK, hade a stimulated effects on all current parameters under study. Even through, all traits were recorded over value with $F_{3}$ compared with $F_{2}$ and $F_{1}$. Moreover statistic results showed that there were significant effects between $F_{3}$ or $F_{2}$ to $F_{1}$. However this increase was insignificant between $\mathrm{F}_{3}$ and $\mathrm{F}_{2}$.

\section{REFERENCES}

Abd El- Kader, A.A., S.M. Shaaban, and M.S. Abd ElFattah, 2010. Effects of irrigation levels and organic compost on Okra plants (Abelmoschus esculentus I.) grown in sandy calcareous soil. Agric. Biol. J. N. Am., 1(3):225-231.

Aboamera, M.A., 2010. Response of cowpea to water deficit under semi-portable sprinkler irrigation system. Misr J. Ag. Eng., 27 (1) : 170- 190.

Alqudah, A.M., N.H.Samarah., and R.E.Mullen., 2011. Drought stress effect on crop pollination, seed set, yield and quality. In: Lichtfouse E (ed) Alternative Farming Systems, Biotechnology, drought stress an ecological fertilization. Springer Science Business Media B V., Sutain. Agric. Rev., 6:193:213.

AOAC., 2005. Officials methods of analysis. Association of official Analytical Chemist, Inc. $18^{\text {th }}$-ed., Virginia. USA.

Beyranv, H., A. Farnia, S. Nakhjavan., and M. Shaban., 2013. Response of yield and yield components of maize (Zea mayz L.) to different bio fertilizers. International journal of Advanced Biological and Biomedical Research. 1(9): 1068-1077.

Carlot, M., A. Giacomini., and S. Casella., 2002. Aspects of plant-microbe interactions in heavy metal polluted soil. Acta. Biotechnol., 22 (1-2): 13-20.

Catello, P., A. M. Palese., G. Celano., and M. Zaccardelli., 2014. Effects of compost tea treatments on productivity of lettuce and kohlrabi systems under organic cropping management. Italian Journal of Agronomy, 9 (596): 153-156.

EAS., 2017. Bulletin of the Agricultural statistics. Part (2). Summer \& nili crop. Ecomomic Affairs sector. Ministery of Agricultureal and Land reckimation (In Arabic)

El- Beltagy A.T., and A.F. Abo-Hadeed., 2008.The main pillars of the national program for maximizing the water-use efficiency in the old land. The Research and Development Council, Ministry of Agriculture and Land Reclamation (MOALR), Giza, Egypt.

El- Khatib, S.I., N.M. El- Bialee., I. Ilham, El- Khatib., and A.M. El- Bialee., 2014. Effect of laser leveling, water quantities and rhizobium inoculation on fixing $\mathrm{N}_{2}$ efficiency with Faba Bean. Agric. Biol. J. N. Am., 5(2): 87-96. 
Farnia, A., and H. Torkaman., 2015. Effect of different biofertilizers on yield and yield components of maize (Zea mays L.). Bull. Env. Pharmacol. Life Sci., (BEPLS), 4 (4): 75-79.

Gomez, K.A., and A.A. Gomez., 1984. Statistical Procedure for Agricultural Research, $2^{\text {nd }}$ ed. John Wiley and Sons Inc., Croda.

Khaled, A. S., Mona, G. Abd El-Kader., and S.M. ElKhadrawy., 2011. Evaluation of organic farm and compost combined with urea fertilizers on fertility and maize productivity in newly reclaimed. Res. J. Agric. \& Biol. Sci., 7(5): 388-397.

Khalill, O. K. O., 2013. Effect of some important factors on the tolerance of some durum wheat varieties for drought. M.Sc., Crop physiology and Poduction. Agronomy Dept. Fac. Agri. Cairo. Al-Azhar Univ.

Klute, A.A.,1986. Methods of soil analysis. Part $1,2^{\text {nd }}$ ed. American Society of Agronomy. Ins publisher, Madison, Wisconson, U.S.A.

Meena, M. D., D. D. Tiwari1, S. K. Chaudhari, D. R. Biswas, B. Narjary, A. L. Meena, B. L. Meena., and R. B. Meena., 2013. Effect of biofertilizer and nutrient levels on yield and nutrient uptake by maize (Zea mays 1.). Annals of Agri-Bio Research, 18 (2): 176-181.
Mohammed, A.S.H., A.A. Ibrahim., and N.M. El- Bialee., 2018. Maximizing water productivity for irradiated cowpea. Asian Journal of Science and Technology, 9 (5): 8079-8084.

Pane, C., G. Celano., D. Villecco., and M. Zaccardelli., 2012. Control of botrytis cinerea, alternaria alternata and pyrenochaeta lycopersici on tomato with whey compost-tea applications. Crop Protection. 38: 80-86.

Rudresh, D. L., M.K. Shivaprakash., and R.D. Prasad., 2004. Effect of combined application of Rhizobium, phosphate solubilizing bacterium and Trichoderma spp. On Growth, nutrient uptake and yield of chickpea (Cicer aritenium L.). Applied Soil Ecology, (28):139- 146.

Suke, S.N., R.D. Deotale, P. Hiradeve, M. Deogirkar., and S.N. Sorte., 2011. Effect of nutrients and biofertilizers of chemical and biochemical parameters of maize (Zea mays L.).J. Soil and Crops, 21(1):107-112.

Umesha, S., M. Srikantaiah, K. S. Prasanna, K.R. Sreeramulu, M. Divya., and R.n. Lakshmipathi., 2014. Comparative effect of organics and biofertilizers on growth and yield of maize (Zea mays. L). Curr. Agri. Res. Jour., 2 (1): 55-62.

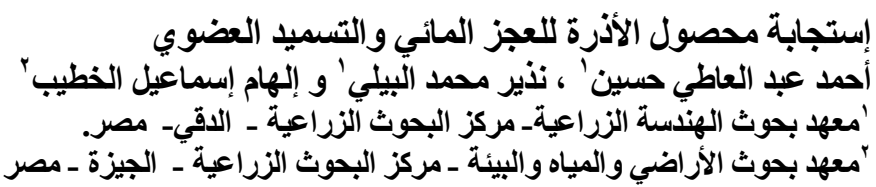

تعظيم إنتاجية وحدة المياه للمحاصيل المروية من خلال التقنيات المختلفة، و التوسع في إستخدام الأسمدة العضوية عوضا عن الأسمدة

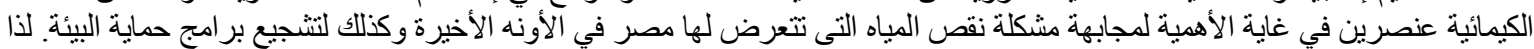

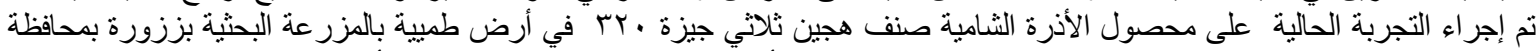

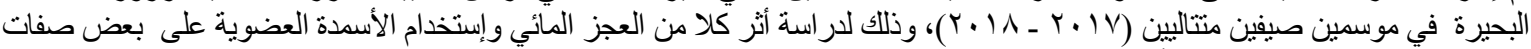

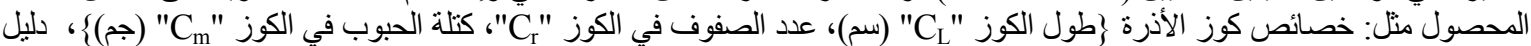

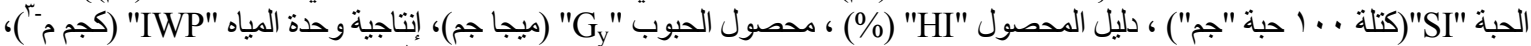

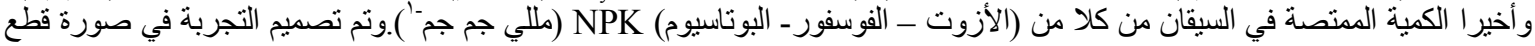

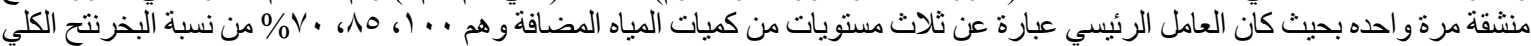

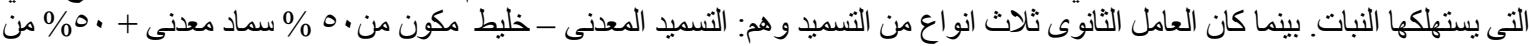

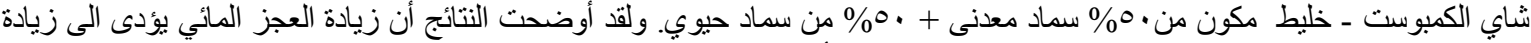

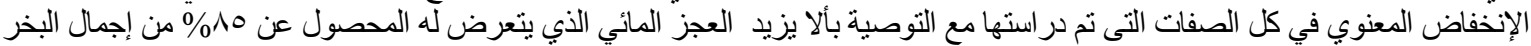

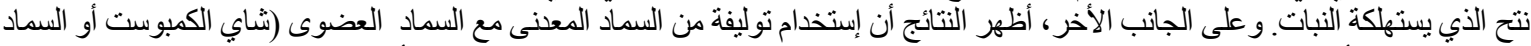

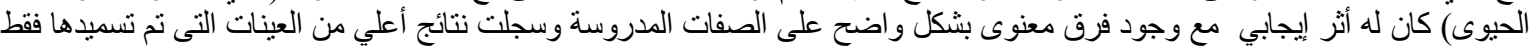

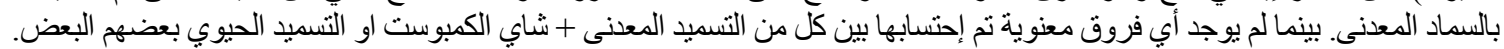

